Revue belge de géographie

3 | 2016

High-speed rail and the city: urban dynamics and tourism

\title{
City planning related to the completion of the new high speed line in Rennes, Brittany
}

The unexpected competition between central projects and peripheral private investments

L'urbanisme lié à l'arrivée de la Ligne à Grande Vitesse à Rennes (Bretagne). La concurrence inattendue entre projets publics en centre-ville et opérations privées en périphérie

\section{Romaric Nègre and Guy Baudelle}

\section{(2) OpenEdition}

\section{Journals}

Electronic version

URL: http://journals.openedition.org/belgeo/18122

DOI: $10.4000 /$ belgeo. 18122

ISSN: 2294-9135

Publisher:

National Committee of Geography of Belgium, Société Royale Belge de Géographie

Electronic reference

Romaric Nègre and Guy Baudelle, « City planning related to the completion of the new high speed line in Rennes, Brittany », Belgeo [Online], 3 | 2016, Online since 30 June 2016, connection on 20 April 2019. URL : http://journals.openedition.org/belgeo/18122 ; DOI : 10.4000/belgeo.18122

This text was automatically generated on 20 April 2019.

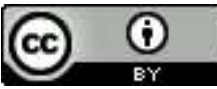

Belgeo est mis à disposition selon les termes de la licence Creative Commons Attribution 4.0 International. 


\section{City planning related to the completion of the new high speed line in Rennes, Brittany}

The unexpected competition between central projects and peripheral private investments

L'urbanisme lié à l'arrivée de la Ligne à Grande Vitesse à Rennes (Bretagne). La concurrence inattendue entre projets publics en centre-ville et opérations privées en périphérie

Romaric Nègre and Guy Baudelle

\section{Introduction}

With a provision scheduled for summer 2017, the Bretagne-Pays de la Loire high-speed line (BPL HSL) between the cities of Le Mans and Rennes will extend the Atlantic HSL commissioned in 1989 from Paris to Le Mans (Figure 1). The new infrastructure will set Rennes, the administrative capital-city of Brittany, less than one hour and half away from Paris compared to the current two hours and ten minutes. 
Figure 1. The BPL HSL within the French high-speed rail network.

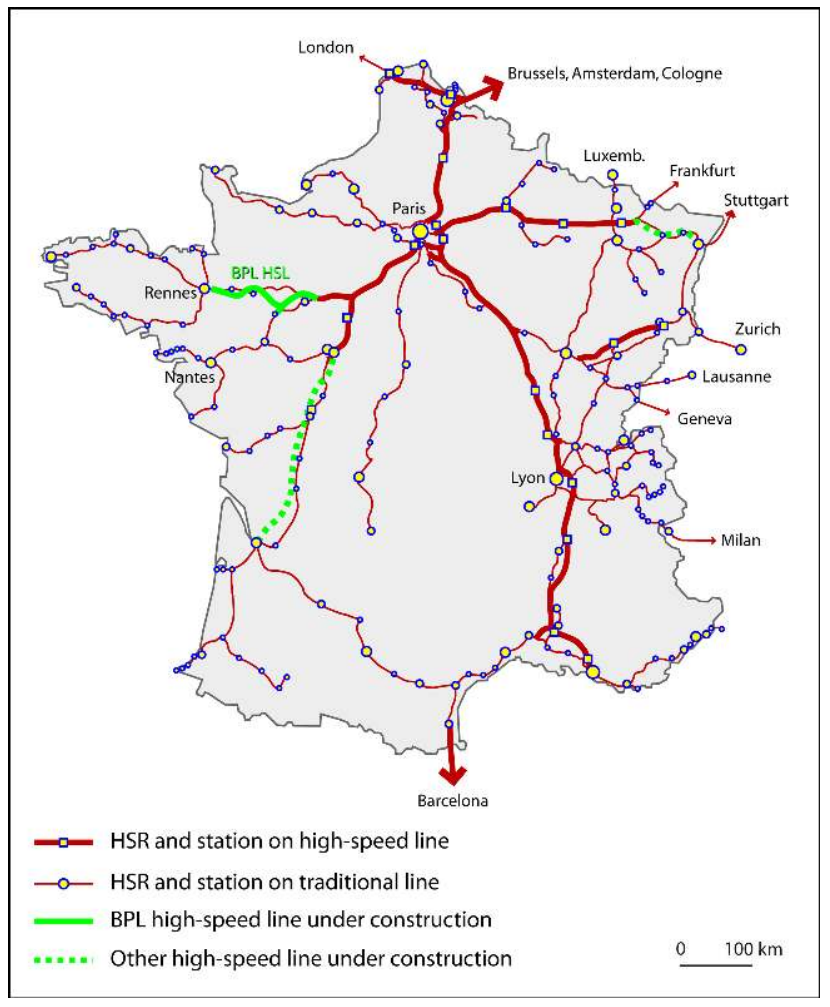

Source: adapted from Wikipedia Commons

2 If time savings will be significant, a sharp breakdown threshold in the global mobility scheme seems unlikely to occur given the current high level services frequency (AUDIAR, 2014). Considering, however, that any HSL is likely to induce "dynamics of amplification and acceleration in pre-existing trends" but rarely to cause a trend reversal (offner, 1993), it is necessary to consider the socio-economic path of Rennes and the territorial integration process of the infrastructure reflected by local actors.

However an extensive literature about the possible effects of HSL on urban growth and especially on the direct and indirect impacts of newly connected (central or peripheral) railway stations on the local real estate office market calls for caution. The state of the art reveals the absence of certainty as to the reality and extent of the possible effects of a HSL (Jensen-Butler \& Madsen, 2005; Bruinsma et al., 2008; Ureña, Ménerault \& Garmendia, 2009; Mignerey, 2012; Baudelle, 2016), including the so-called "structuring effects" (Offner, 2009 \& 2014). The very first HSLs have raised the same hopes and concerns (Offner, 1993) while the HSRs under construction abroad give rise to contradictory scientific expectations considering these uncertainties (Kantor, 2008; Randolf, 2008; Todorovitch, 2011; Lee, 2007). The misfortunes of high-speed rail in Spain have led to many contradictory tests to estimate its impact (Esteban 1998; Gutierrez Puebla, 2004; Bellet et al, 2010; Terrin, 2011; Garmendia et al, 2012; Facchinetti-Mannone et al., 2013; Richer, 2014). The recurrent nature of such research only demonstrates that knowledge remains uncertain since the earliest Japanese works on Shinkansen (eg. Hirota, 1985 \& Ino, 1986).

Certainly a number of focal points have been confirmed from one study to another. It is thus noted that existing industries can grow after the HSL arrival but also face new 
competition from outside companies. The case of Lyons (Bonnafous, 1987) has demonstrated that high-level business services have successfully competed with Paris by enhancing their skills on specific niches responding to the demand of SMEs. Locally new office surfaces around the stations may lead to the relocation of existing ones (Bazin et al., 2009) or even catch outside companies (cases of Lyons, Le Mans, Nantes and Rennes) due to the will to capture a modernity image impact (SETEC, 2004) and even take advantage of a "supermodernity" effect (Nicolin, 1995). Generally speaking the emergence of highspeed rail has little effect alone given that such an innovation (as defined by the geographical theory (Hägerstrand, 1952)) needs to be accompanied by other measures to increase its economic reach including office programs or improvement of regional and urban transport. A new HSL does not in itself guarantee new investments as demonstrated by many cases of overinvestment in office real estate and oversized projects around the HSL stations (Plassard, 2003; Bazin et al., 2011; Delaplace et al., 2013). The impact on office dynamics seems stronger in larger metropolises (Mannone, 1997) but even in large metro areas like Lille the investment has proved to be hazardous (Ménerault, Barré, 2001).

5 More recently but similarly, many "HSL" stamped real estate projects planned during the economic boom have been caught by the crisis. For instance, in Rotterdam, the HSL implementation has doubled in a year the office space available in the city centre. But the market failed to keep pace so that the surfaces sold off in 2015 were three times lower than in 2008, leaving a third of the stock empty despite the settlement of the police department's imposing building (NVM, 2015). Short distance relocations within the metro area and effects of anticipation are rather common but do not establish the HSL as the decisive factor (Delaplace et al., 2013; Delaplace, 2009).

Thus the term HSL opportunity should be preferred to the more common ones of "effects" or "impacts". Firstly because at this stage we can only situate our work in a forwardlooking approach as we aim to identify the appropriation strategies of actors and their spatial implications. Secondly because we will demonstrate that the HSL is not the Rennes metropolitan project's ultimate purpose. It would then be risky and inappropriate to isolate the involvement of the HSL from the global metropolitan dynamics.

7 This paper intends to shed light on the strategies related to the HSL BPL opportunity by Rennes local public actors through an analysis of the city's economic trajectory, its territorial positioning and ongoing urban infrastructures. The latter are indeed interesting indicators to evaluate both the strategies implemented by the actors of the local system and the spatial transformation process (Bérion, 1998). Our contribution is divided into three parts. The first one suggests that Rennes economic path exhibits a potential for exploiting the "HSL opportunity". Then it is shown the extent to which the metropolitan communication strategy has been reoriented to account for the HSL project. Finally it is stated that the high expectations are facing an unexpected competition by peripheral investments, leading to reassess the HSL opportunity and eventually the city development strategy itself. 


\section{Economic orientations: an innovative city likely to take advantage of the coming HSL}

For a long time, Brittany has been considered as a remote and peripheral area to such an extent that even Rennes, its regional capital-city, was usually seen as a badly connected city (Baudelle, Guy, 2004; Havinden, Quéniart \& Stanyer, 1991). The local take-off only happened in the 1960s thanks to a manufacturing relocation process outside of Paris metropolitan area followed by the development of new higher education institutions (Baudelle, 2008). A typical snowball cumulative effect has happened since the 1980s, making the city a technopole (high-tech city) namely with electronics, telecommunications and later computing as fields of excellence. This success story explains why the impressive population growth occurred (Paulus, 2004) before the construction of the first HSL section between Paris and Le Mans that has shortened in 1989 the travel time between Paris and Rennes to less than 2 hours fifteen, the gain exceeding an hour. The agglomeration (that is, the built up area) has grown up from 234000 (1982) to $322000 \mathrm{inh}$. in 2013 while the functional urban area - officially called aire urbaine and defined as the travel-to-work area (TTWA) for at least $40 \%$ of the workforce -, has reached $680000 \mathrm{inh}$. (Clanché, 2014). Rennes shares its high rate of development with other technology-driven cities (Figure 2).

Figure 2. 30 years of urban dynamics: annual population change (in \%) of the four largest French agglomerations and of the main high technology centres from 1982 to 2011.

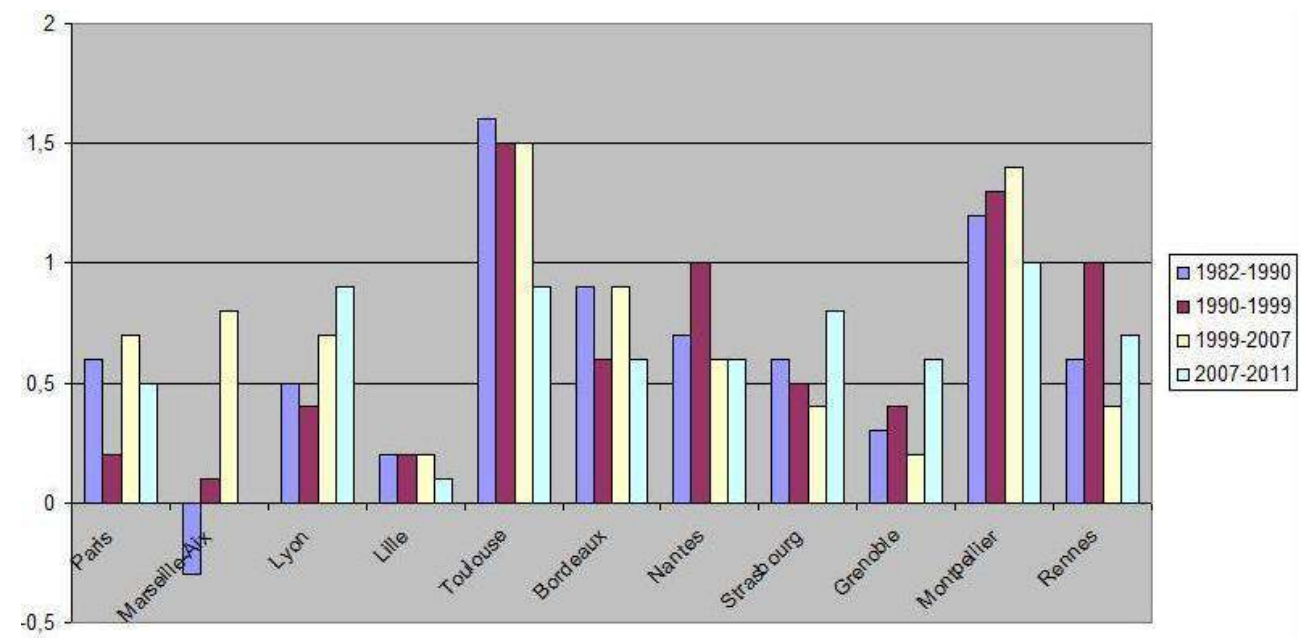

NB: NO BAR APPEARS IN CASE OF ZERO CHANgE.

SOURCE OF THE DATA: INSEE

Due to its academic weight and to its development based on innovative industries, Rennes has got a high share of higher strategic functions approximated by the index of professionals of metropolitan functions (PMFs) (CFM: cadres des fonctions métropolitaines) elaborated by the French National Office for Statistics (INSEE). These functions refer to five professional, knowledge-intensive industries: management, business between firms, R\&D, intellectual services and finally culture and entertainment. Outside Paris, Rennes had the $8^{\text {th }}$ concentration in 2006. The development was particularly high from 1999 to 2008 (Figure 3) due to a diffusion process from Paris towards the main regional capital 
cities (INSEE, 2009a; Van Puymbroeck \& Reynard, 2010; Agences d'urbanisme de l'Espace Loire-Bretagne, 2010; Observatoire des territoires, 2015).

Figure 3. Change in professionals of metropolitan functions in the main French metro areas between 1999 and 2007.

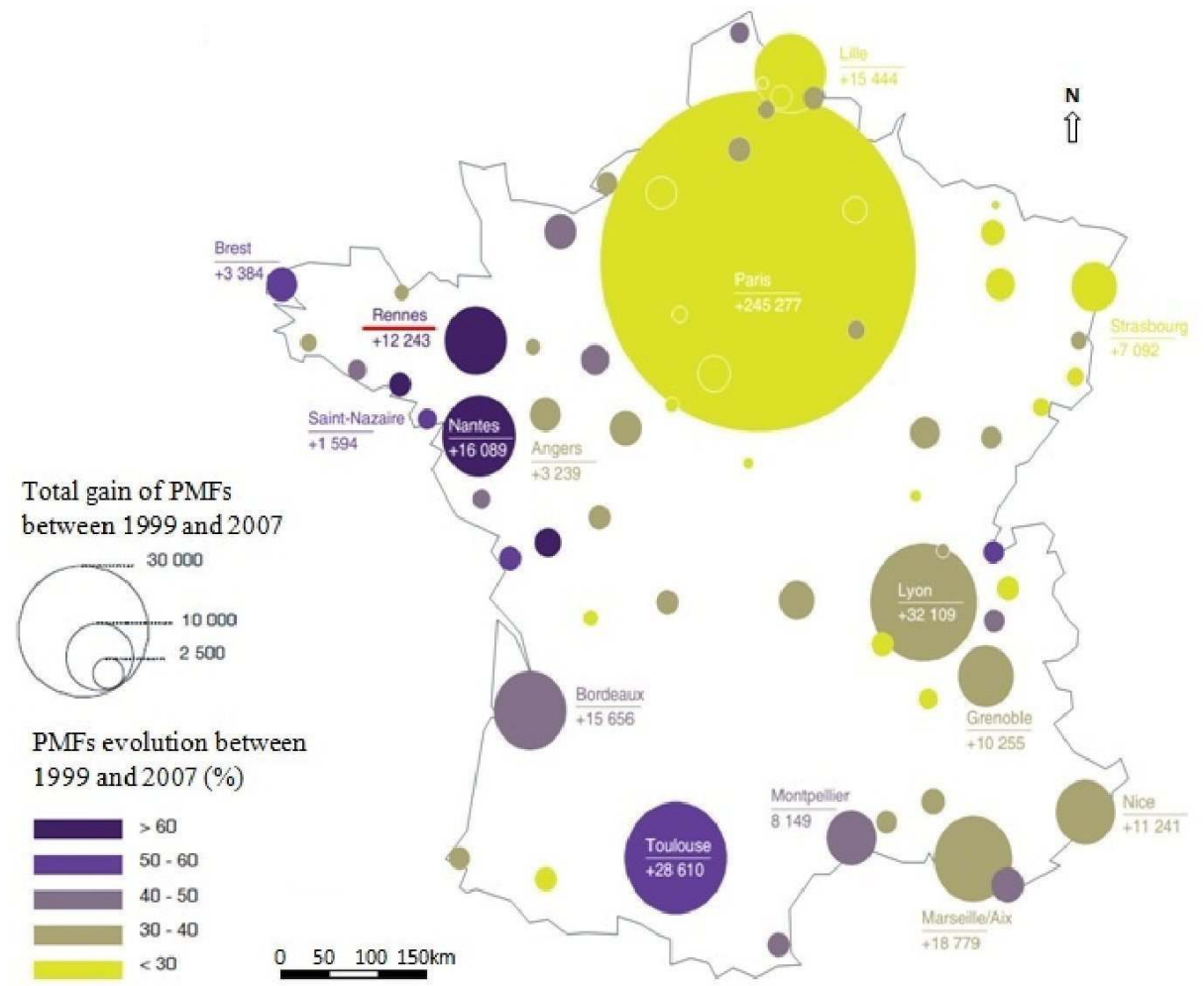

Source: Agences d'urbanisme de l'Espace Loire-Bretagne, 2010

10 This is confirmed by the concentration of members of the so-called creative class (within the meaning of Florida's (2002) theory). According to INSEE, the creative core class represents the basis of the creative class as it is more significant of innovative capacities than the other ones (professionals and bohemians). The calculation shows that Rennes belongs to the top 7 among the large metro areas (INSEE, 2009b).

11 The ICT sector is very dynamic compared to other cities with an increase of nearly $10 \%$ from 1995 to 2011, so that two thirds of the 20,000 private jobs in consulting and expertise are part of the digital economy (AUDIAR, 2012). The correlation between innovative industries, high share of professionals and economic performance would explain the job dynamics trend observed among the regional cities since the mid-1970s until now (DATAR, 2012 \& 2013).

Between 1998 and 2009, the annual employment change rate was $1.7 \%$ in the Rennes TTWA to compare with the national mean $(+0.8 \%)$. The unemployment rate has increased only by 0.9 (in points) from the beginning of 2003 to the end of 2011 versus 1.1 at the national level (Mas, 2011). The resilience since the 2008-2009 has been better so that the unemployment rate was $8.1 \%$ only at the beginning of 2015 versus $10.3 \%$ at the national level, making Rennes $55^{\text {th }}$ among more than 300 employment areas. At the end of 2014, Rennes was awarded (as nine other candidates) by the State's "French Tech" label which rewards the dynamism and international standing of its start-ups. 
13 Due to its favourable economic basis, one could expect that the forthcoming HSL would enhance again the economic development of Rennes. However, despite its economic performances, the city has some weaknesses explainable by its size - it is only the $11^{\text {th }}$ French agglomeration -, particularly in terms of international fame (AUDIAR, 2014), explaining the high expectations about the future infrastructure (AUDIAR, 2012).

\section{A radical and difficult shift in the communication strategy} xity remain the fertile soil for the local image, the focus is significantly turning towards the national and international levels. Due to the increasing competition between cities, Rennes as a second tier regional metropolis seeking internationality is moving towards a proactive economic development based on its amenities (Jouve, Lefebre, 2004). This change in the objective, size and design of the territorial offer is supported by an "actorial turn" (Houllier-Guibert, 2008) that highlights the rising claim of the role of the Rennes metropolitan authorities in "designing the future" and enhancing the (too weak) international profile.

What is the influence of the HSL BPL project on such a strategic turn? Is it the trigger, the catalyst or the endower of legitimacy? The answer is not obvious. Still, the accessibility allowed by the HSL is an opportunity for the metropolitan area to reconsider its attractiveness strategy, especially as the level of facilities in sport, culture and accommodation is considered poor compared to other French cities, Rennes remaining at the level of Nancy ( $20^{\text {th }}$ French FUA) according to the local planning agency itself (AUDIAR, 2012c). The redefining of the metropolitan project for a greater (inter)national visibility fosters reflections on the city's image outside local borders. However, for some authors the image effect of HSR hardly exceeds the intra-regional scale, at least in the short run (Willigers, 2008; Bazin et al., 2009). Unlike some French similar regional cities such as Bordeaux or Toulouse, respectively spontaneously associated with wine and aerospace, the capital of Brittany definitely suffers from a lack of image (AUDIAR, 2014), in particular on the economic front (Houllier-Guibert, 2012). Its identity depiction is as complex as instructive. Frequently associated with Brittany, a region that is surrounded by an international aura through a strong traditional symbolism (Oco Global, 2007), Rennes is in a sense paradoxically embarrassed by the deep Breton cultural identity that contrasts with its modern territorial stance and hinders its economic and technological image (Chapuis, 2013). Like Strasbourg and Alsace, the coherent articulation between the regional image and the "city picture" is being discussed. The Rennes Development Agency 
asserts for instance that "the challenge is, in the future, to be able to identify Rennes with no exclusive link with Brittany" (AUDIAR, 2014, p. 3).

In addition to remain sustainable, the current building up of the renewed image of Rennes has to be thought in the light of the specific territorial resources. In our view, the "desire of territory" should not emerge from an "utopisation process" (Thiard, 2007) or be limited to cultural events - a strong feature of the territorial ideology in Rennes - but should rather aim at reaching a long-term differentiation in connection with local factors (Bertolini, Spit, 1998). The urban aesthetic values are surely powerful levers of exogenous attractiveness but territorial hospitality and quality of life cannot be considered as an exclusivity of Rennes and "are insufficient to stimulate an internationalisation process" (AUDIAR, 2014, p. 2). However, the high-tech city status that we have stated represents a powerful vector of external visibility. Indeed, it captures and emphasizes the excellence of the local economy, the innovative capacity of its digital ecosystem as well as the quality of higher education institutions.

\section{The public urban projects: high expectations but strong local competition}

\section{The city planning strategy: seeking for the optimal valuation of the HSL opportunity}

In this part of the paper we aim at reading the metropolitan project in the light of the two major territorial ideologies-seemingly hardly reconcilable- of proximity and internationality, as it is from these ambitions that the urban project integrating the coming HSL is embodied. Indeed in this attempt to find the "genius loci" (Gumuchian, Pecqueur, 2007) that could differentiate Rennes among the European cities, the metropolitan project is a major lever for the territorial marketing of Rennes (HoullierGuibert, 2009), considering "the urban project as a strategic tool that formalises the forward-looking ideas" (Tsiomis, Ziegler, 2007). Doing so it demonstrates the ability to achieve a political consensus and to structure a local governance that includes the highspeed line in its strategic vision (Bazin et al. 2006). The project also reflects the will of local actors to manage and value land, especially near the train station.

The international outreach strategy is detectable through the density of planning achievements which aim to increase the desirability of Rennes with regard to highly qualified professionals. The /International city /building designed to host invited foreign scientists and postgraduate students willing to conduct research in Rennes has opened by the end of 2015. In 2018, around one year after the provision of the HSL BPL, the new Convention Centre will be completed in the heart of the historical centre. The monitoring and promotion of these new facilities are implemented by "Destination Rennes", a new Société Publique Locale (Publicly-owned Local Corporation) supposed to become the single organisation of the metropolitan area devoted to the promotion of Rennes.

However, it should be noted that these projects are more about catching-up involvements to overcome the current internationality deficit than about bold and distinctive prospective policies. Ranked last among the 12 major French cities in the hosting of conferences and exhibitions by the ICCA ${ }^{1}$ in 2012, Rennes is expected to absorb its shortcomings thanks to the Congress Centre (AUDIAR, 2012) more than to intensify 
comparative advantages. All the more so as the improvement of its territorial offer for highly educated individuals is linked to the achievement of standard facilities, or at least facilities which are not basically able to encourage a clear differentiation vis-à-vis other similar metropolises.

Fortunately, according to Trip (2007), the HST has an international image. It also remains associated to a smart way of travelling and still enjoys a fashionable image sometimes related to the striking architecture of its new glorious railway cathedrals. The expected HSL-fuelled future development is supposed to change the city perception into a selffulfilling growth process also supported by the quality of place - in the sense of Florida and Jane Jacobs - and urban design improvements to which the type of attracted firms are supposed to be sensitive. A large-scale urban development could happen thanks to landmark buildings and conceptions of the railway station both as a node and a place (Trip, 2007).

The potential for translating the HSL opportunity into comparative advantages is a priori more in the pursuit of a high level of accessibility at the railway station in Rennes (AUDIAR, 2012). Intimately linked to the HSL project, the second metro line to be inaugurated in 2019 will enable, complementarily with the first one, to easily "slide" (Ménerault, Barré, 2001) from an inter-metropolitan mobility to an intra-metropolitan mobility. This "last mile" management, so damaging to some high-speed rail stations (notably "ex-urbanised stations") (Ollivro, 1999; Troin, 2010), will potentially lead to a seamless transport without too constraining transfers. In a sense, it shows the local actors' willingness to add an extraterritorial function to the local scope of the metropolitan network through the HSL. By connecting the train station and its business district, the technological park Rennes Atalante, the International City, the Convention center and the University campuses, the metro network "endeavors to order the articulation between the constitutive parameters of the [external reach] of the city" (Tsiomis, Ziegler, 2007, p. 190). By virtue of its layout, the second underground line conveys a clear high-end service sector dimension when the first line rather proceeded from social issue by connecting the most densely populated, class neighbourhoods (Figure 4). Thus interrelated, the different metropolitan achievements concomitant to the HSL introduce an organic reconstruction of Rennes urban area.

\section{The unanticipated competition from peripheral office locations}

However, such an urban growth strategy introduces a sharp competition, exacerbated by land pressure fostered by the coming HSL, between central and peripheral business districts. Indeed, the latter benefit from accessibility levels similar to core business centres and take advantage of larger surfaces available as well as lower land prices. The latest example refers to the establishment of the Crédit Agricole bank local headquarters in La Courrouze ZAC, an Urban Development Zone of 115 ha sized to $100,000 \mathrm{~m}^{2}$ of business activities and 5,000 housing units by 2025. Located along the ring road, the new building combines the advantage of a strong accessibility by road and air from outside and by local public transport as well due to the future metro line connecting it to the central station in 7 minutes only (Figure 4). In a sense, the nodal intensity in terms of feeder traffic (Richer, Vuidel, 2011) experienced by the railway station of Rennes is paradoxically jeopardising the EuroRennes project around the station area. In the constant pursuit of accessibility gains, what we consider as time savings should be regarded as space savings, 
because higher average speeds may be reinvested to reach more distant destinations (Joly, 2003). Conversely office central locations close to the station may suffer worse road accessibility and even by public transport due to the possible lack of central car parks and park-and-ride facilities by metro line heading.

Figure 4. Interrelated planning projects and development zones in the agglomeration of Rennes.

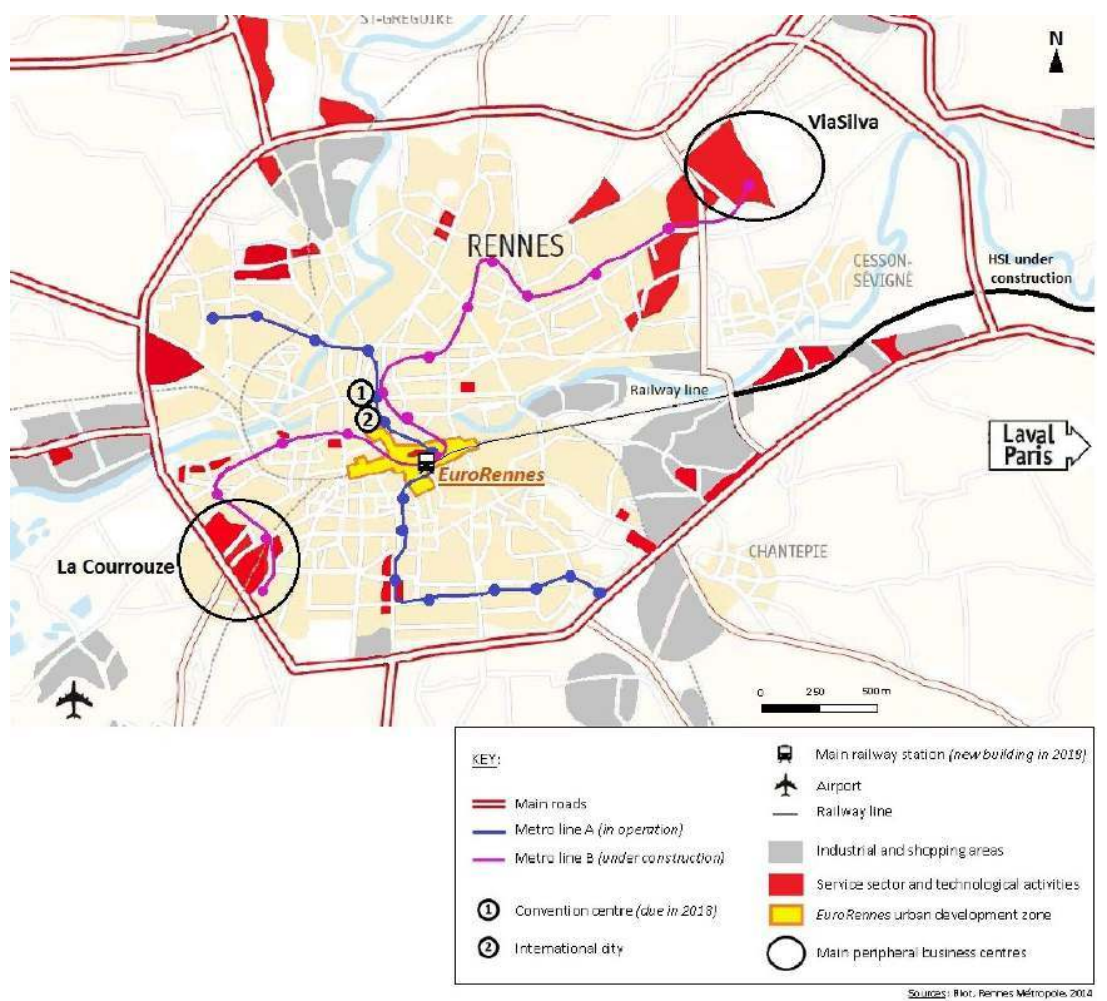

Despite this competition, the new economic showcase of the Brittany's capital city remains embodied by the ambitious EuroRennes program even if public support policies implemented to grab the "HSL opportunity" are clearly not limited to planning projects around the station area (AUDIAR, 2012). Architectural signals convey the ambition of prestige and international outreach: $125,000 \mathrm{~m}^{2}$ dedicated to office activities, 1,400 housing units, a vast vegetated esplanade crossing the new exchange terminal, a 80-metre tower... Many flagship constructions designed to make EuroRennes an "appealing product" for Brittany (Figure 5). 
Figure 5. Model of EuroRennes project on a presentation leaflet by Rennes Metropole.

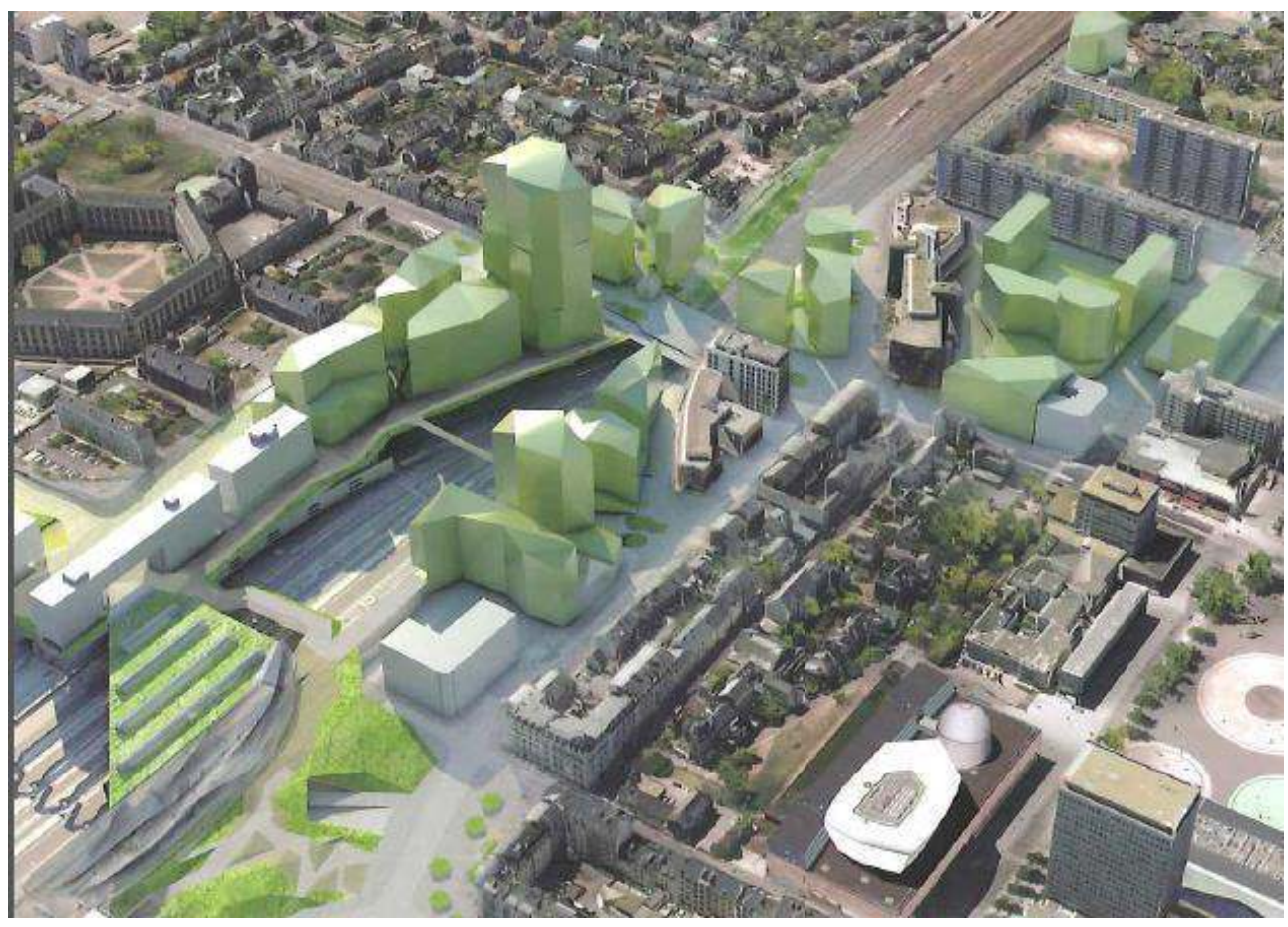

Source: Rennes Metropole

\section{contraction in the initial project's scope and some form of listlessness in the marketing} pace. Such rescaling and fragmentation of the project are not specific to Rennes. Evidences come from previous similar planning achievements which have experienced a declining trend like Novaxis (Le Mans) or Euralille, whose current activity masks an extended market depression in the filling of business premises (Ménerault, Barré, 2001). Already, during the previous renovation of the Rennes station area (1990-1998) for the arrival of the TGV, difficulties in establishing an ambitious new service-sector hub in the city centre led to the reduction in surfaces allocated to office properties ${ }^{2}$ (Ménerault, Barré, 2001). At that time, the competition from peripheral business districts emerged as an explanation for this lack of targeting. For all that, can we really assert that the same process applies today concerning the EuroRennes project? The global regulation policy of new office volumes orchestrated by the metropolitan authorities and issues surrounding the temporality of planning tempt to moderate such an internal competition. Indeed in 2010, following national laws and regulations concerning the management of local public services, the Urban Community of Rennes created a single GIE (Group of economic interest) consisting of three publicly-owned local planning corporations dedicated to all programs of metropolitan interest. Under political control from design to completion, development projects integrate the metropolitan strategic guidance. Within this context, the EuroRennes project needs to be put into perspective with other key programs, among them the two peripheral major land transactions of La Courrouze and ViaSilva (Figure 4).

seeming competition then conceals different times in the implementation of the three main high-end service sector districts in Rennes (Figure 6). The current commercial difficulties encountered by EuroRennes and the recent setting of key accounts in La Courrouze and ViaSilva can partially be explained by the maturity of these peripheral 
programs, whilst for now EuroRennes does not offer any completed office surface for potential investors. If it seems in the nature of local authorities to "place high the cursor of territorial optimism" (Guillier, 2002), the EuroRennes project shows the limited ability of local actors in creating a stimulating effect which sets the private market in motion with a two or three-year time frame, especially when a competitive and often substitutable offer of new office space already exists. Previous local public stakeholders involved in planning office buildings acknowledge their total dependence on real estate cycles.

Figure 6. Distinct paces of development for the three strategic high-end service spaces.

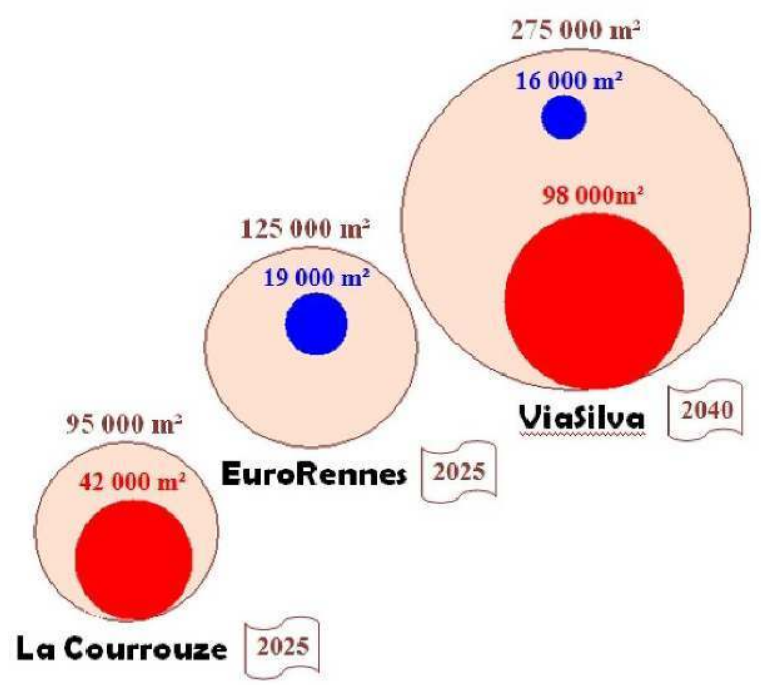

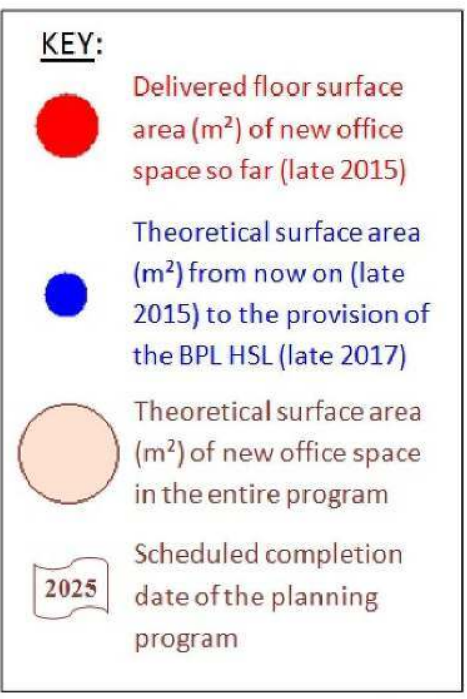

Source : Territoires, Rennes Métropole

However, the temporary suspension of new office completed in La Courrouze and the imminent arrival of the BPL HSL have initiated the first real estate transactions in EuroRennes. In November 2015, a national SCPI ${ }^{3}$ (Civil Property Placement Company) acquired the assets, in a VEFA (sale before completion) contract, of the Urban Quartz program orchestrated by two national promoters (Figure 7). According to a local player, this first ever acquisition of real estate assets in Rennes by a leading national property company is a tangible sign of the new dimension reached by the local high-end real estate market. Concerning the commercial launch, little or no information have been passed on. Seeking to a new installation, a local business law firm would be in the process of finalising a transaction in the Eurosquare program and a major insurance group is watching with interest an eventual more centrally located development. The pioneering investors also hope to attract companies currently settled in the outer suburbs of Paris where the square meter is the same price but without any central location advantage. Anyway the question is whether EuroRennes will remain an adjustment variable of the new office market in Rennes or be able to act as the pilot high-end service sector centre long awaited by local authorities. It is probably still too early to answer. 
Figure 7. The three main development programs in EuroRennes: different players, dynamics and temporalities.

\begin{tabular}{|l|l|l|l|}
\hline $\begin{array}{l}\text { Key office } \\
\text { development } \\
\text { programs before } \\
\text { mid-2018 }\end{array}$ & Promoters involved & $\begin{array}{l}\text { Square } \\
\text { meters of } \\
\text { office usable } \\
\text { floor space }\end{array}$ & $\begin{array}{l}\text { Scheduled } \\
\text { completion } \\
\text { date }\end{array}$ \\
\hline URBAN QUARTZ & $\begin{array}{l}\text { National promoters : Icade (the Caisse } \\
\text { des Dépôts et Consignations' public real- } \\
\text { estate subsidiary) and La Poste immo } \\
\text { (real-estate subsidiary of the La Poste } \\
\text { Group) }\end{array}$ & $12980 \mathrm{~m}^{2}$ & Late 2017 \\
\hline EUROSQUARE & Regional promoter : Giboire & $5900 \mathrm{~m}^{2}$ & Late 2017 \\
\hline IDENTITY ${ }^{3}$ & Regional promoter : Giboire & $18876 \mathrm{~m}^{2}$ & Mid-2018 \\
\hline
\end{tabular}

\section{Conclusion}

Anticipation and support strategies to value the HSL opportunity implemented by Rennes public actors are hardly dissociable from a comprehensive metropolitan project in which the high-speed infrastructure is only one piece of a large puzzle. To some extent, the BPL HSL has sounded like a profound trigger for the reorientation of Rennes strategy and a catalyser for a common vision (Terrin, 2011) - what Bérion (1998) would call the participatory effects of a new transport infrastructure. The approval on the "2020 Urban Community Program" has led local institutions to shift their territorial focus towards Europe, putting forward local socio-environmental amenities and distinctive economic assets such as ICT, agro-food industry and R\&D ecosystem. In other words, it aims at enhancing the reach and clarity of the local economic potential (AUDIAR, 2012). As part of this prospective strategy, the HSL has to be seen as a permissive effect (Bérion, 1998) for an increased valuation of Rennes socio-economic dynamism. If the arrival of the infrastructure in 2017 is stimulating a catch-up in the business tourism sector through new facilities that emphasized an asserted international status, it creates with the new metro line system a functional change inside the metropolitan area. However, despite being driven by strong inter-municipal governance, the local territorial transformation remains complex. Intra-territorial competitive pressures between interrelated business districts and global economic conditions seem to have annihilated the initial optimism around the EuroRennes project, symbolic showcase of an expected international appeal. A clear sign that anticipation and support public policies are necessary but not sufficient conditions (Bazin et al., 2006) to lay the foundations of a successful territorial insertion for a HSL. 


\section{BIBLIOGRAPHY}

AGENCES D'URBANISME DE L'ESPACE LOIRE-BRETAGNE (2010), « Les cadres des fonctions métropolitaines », Dynamiques métropolitaines de l'Espace Loire-Bretagne, 1, http://www.audiar.org/ sites/default/files/etudes/fichiers/emlb2010_n1_cadres.pdf, retrieved 10/10/2015.

AUDIAR (Agence d'urbanisme et de développement de l'agglomération rennaise) (2012a), Les effets de Bretagne à Grande Vitesse dans l'agglomération rennaise, Rennes, 56 p.

AUDIAR (2012b), Ancrage et pérennité des services aux entreprises et aux personnes sur le territoire rennais, Rennes, 4 p., http://www.audiar.org/sites/default/files/etudes/economie/ecoservices_entreprises-rennaises_web.pdf, retrieved 10/10/2015.

AUDIAR (2012c), Les grands équipements métropolitains. Le positionnement moyen et équilibré de Rennes vis-à-vis de 14 métropoles françaises, Rennes, $28 \mathrm{p}$.

AUDIAR (2014), L'attractivité internationale de Rennes : positionnement dans les classements et éléments d'appréciation de son image et de sa renommée, Rennes, $12 \mathrm{p}$.

BAUDELLE G. (2008), « La Bretagne. Une région périphérique... à la pointe de l'aménagement », in JEAN Y. \& VANIER M. (eds.), La France: aménager les territoires, Paris, Armand Colin, pp. 126-140.

BAUDELLE G. (2016), « La grande vitesse ferroviaire accélère-t-elle la croissance des villes ? », Place Publique (Rennes et Saint-Malo), 39, pp. 40-44.

BAUDELLE G., GUY C. (2004), The peripheral areas of Western Europe and EU regional policy: prospective scenarios, Paper presented at Regional Studies Association Conference "Europe at the Margins: EU Regional Policy, Peripherality and Rurality", April 15-16, Angers, 10 p., http://michau.nazwa.pl/ aska/uploads/Students/guy_guy.pdf, retrieved 10/10/2015.

BAZIN S., BECKERICH C. \& DELAPLACE M. (2006), Analyse prospective des impacts de la Ligne Grande Vitesse Est-Européenne dans l'agglomération rémoise et en région Champagne-Ardenne, Final report to Champagne-Ardenne Regional Council, 555 p., http://www.voiesnouvellestgv.webou.net/ document/epine/annexes/19analyseimpacts.pdf, retrieved 10/10/2015.

BAZIN S., BECKERICH C. \& DELAPLACE M. (2009), « Desserte TGV et localisation des entreprises sur les quartiers d'affaires : nouvelle accessibilité ou nouvelle offre immobilière de bureaux ? Le cas de la gare centre de Reims ", Les Cahiers Scientifiques des Transports, 6, pp. 37-61.

BAZIN S., BECKERICH C., BLANQUART C., DELAPLACE M. \& VANDENBOSSCHE L. (2011), « Grande vitesse ferroviaire et développement économique local : une revue de la littérature ", Recherche, Transports et Sécurité, 27, 106, pp. 215-238

BELLET C., ALONSO P. \& CASELLAS A. (2010), "Infrastructuras de transporte y territorio. Los efectos estructurantes de la llegada del tren de alta velocidad en España”, Boletín de la Asociación de Geógrafos Españoles, 52, pp. 143-163.

BÉRION P. (1998), « Analyser les mobilités et le rayonnement des villes pour révéler les effets territoriaux des grandes infrastructures de transport ", Cahiers Scientifiques du Transport, 33, pp. 109-127.

BERTOLINI L., SPIT T. (1998), Cities on rails: the redevelopment of railway station areas, London, Spon, $256 \mathrm{p}$. 
BONNAFOUS A. (1987), "The regional impact of the TGV”, Transportation, 14, 2, pp. 127-137.

BRUINSMA F. et al. (eds.) (2008), Railway Development Impacts on Urban Dynamics, Heidelberg, Physica, $419 \mathrm{p}$.

BRUTEL C. (2011), « Un maillage du territoire français. 12 aires métropolitaines, 29 grandes aires urbaines ", INSEE Première, 1333, 6 p.

CHAPUIS J.Y. (2013), Rennes, la ville archipel, an interview by J. Viard, La Tour d'Aigues, L'Aube, 176 p.

CLANCHÉ F. (2014), « Trente ans de démographie des territoires Le rôle structurant du bassin parisien et des très grandes aires urbaines ", Insee Première, 1483, 4 p., http://www.insee.fr/fr/ffc/ ipweb/ip1483/ip1483.pdf, retrieved 10/10/2015.

DATAR (2012), Dynamiques, interdépendance et cohésion des territoires, Rapport de l'Observatoire des territoires 2011, Paris, La Documentation française, 232 p., http : http://www.observatoire-desterritoires.gouv.fr/observatoire-des-territoires/sites/default/files/documents/ Rapport_Obs_2011_synthe\%CC\%80se_EN.pdf (English summary).

DATAR (2013), La mise en capacité des territoires, « DATAR 2040 » Programme, http:// www.datar.gouv.fr/sites/default/files/datar2040_enjeux_capacitation.pdf, retrieved 10/10/2015.

DELAPLACE M. (2009), Histoires d'innovations dans l'espace : de l'émergence d'innovations fondées sur la science à l'appropriation d'une innovation de service de transport, Habilitation à diriger des recherches, vol. 1, Reims, University of Reims-Champagne-Ardenne, $128 \mathrm{p}$.

DELAPLACE M., BAZIN S., BECKERICH C. \& BLANQUART C. (2013), Les enjeux et opportunités de la Grande Vitesse Ferroviaire en termes de développement local et de développement durable : une analyse fondée sur la production et l'appropriation des innovations de services, Université de ReimsChampagne-Ardenne, https://halshs.archives-ouvertes.fr/hal-01098691/document, retrieved 26/01/2016.

DUMONT G.F. (2007), Les métropoles régionales intermédiaires en France : quelle attractivité ?, Paris, La Documentation française, $87 \mathrm{p}$.

DUPUY G. (1999), "From the 'magical circle' to 'automobile dependence' measurements and political implications", Transport Policy, 6, pp. 1-17.

ESTEBAN M. (1998), "La alta velocidad ferroviaria en la Union Europea. Su impacto urbano en Francia y España (High Speed Rail in the European Union. Urban impact in France and Spain)", Geographicalia, 36, pp. 19-32.

FACCHINETTI-MANNONE V. et al. (2013), « Les petites agglomérations françaises et espagnoles face à la grande vitesse ferroviaire : comment convertir l'accessibilité en attractivité ?, Les Cahiers Scientifiques du Transport, 63, pp. 3-31.

FLORIDA R. (2002), The rise of the creative class, and how it's transforming work, leisure, community and everyday life, New York, Basic Books, 416 p.

FNAU (Fédération nationale des agences d'urbanisme) (2012), « Les grandes aires urbaines françaises. Un essai de typologie ", Les Dossiers FNAU, 24, 16 p., http://www.fnau.org/file/news/ FNAU\%20aires\%20urbaines\%20mdef\%20simple.pdf, retrieved 10/10/2015.

FNAU (Fédération nationale des agences d'urbanisme) (2014), « La crise, l'industrie et les territoires », Les Dossiers FNAU, 30, 24 p., http://www.fnau.org/file/news/FNAU\%2030\% 20INDUSTRIE\%20BD\%20simple.pdf, retrieved 10/10/2015. 
GARMENDIA M., RIBALAYGUA C. \& UREÑA J.M. (2012), "High speed rail: implication for cities”, Cities, 29, 2, pp. 26-31.

GUILLIER C. (2002), Imitation et/ou innovations dans les politiques publiques de communication des villes?, Master Dissertation, Department of Communication Science, University Rennes 2, $111 \mathrm{p}$. GUMUCHIAN H., PECQUEUR B. (2007), La ressource territoriale, Paris, Economica, 252 p.

GUTIERREZ PUEBLA J. (2004), "The high-speed train and its spatial effects”, Investigationes Regionales, 5, pp. 199-221.

HÄGERSTRAND T. (1952), "The propagation of innovation waves”, Lund studies in geography: Series $B$, Human geography, 4, Lund, Royal University of Lund, 21 p.

HAVINDEN M.A., QUENIART J. \& STANYER J. (eds.) (1991), Centre et Périphérie. Bretagne, Cornouailles-Devon: étude comparée/Centre and Periphery : Brittany and Cornwall \& Devon compared, Exeter, Exeter University Press, 260 p.

HECKER A. (2010), « De l'impact du TGV sur deux quartiers de gare : Nancy Grand Coeur et Metz Amphithéâtre », Belgeo [En ligne], 1-2 | 2010, mis en ligne le 06 décembre 2012, consulté le 10 février 2016, http:// belgeo.revues.org/6868

HIROTA R. (1985), "Present situation and effects of the Shinkansen", Transport Policy and Decision Making, 3, pp. 255-270.

HOULLIER-GUIBERT C.E. (2008), Les politiques de communication rennaises pour un positionnement européen. Idéologies territoriales et images de la ville, $\mathrm{PhD}$ in Geography, University Rennes 2, $539 \mathrm{p}$.

HOULLIER-GUIBERT C.E. (2009), « Evolution de la communication territoriale : les limites de l'idéologie de la proximité ", Les Enjeux de l'Information et de la Communication, 1, pp. 45-61.

HOULLIER-GUIBERT C.E. (2012), « De la communication publique vers le marketing des territoires : approche microsociologique de la fabrication de l'image de marque ", Gestion et Management public, 1, 2, pp. 35-49.

INO T. (1986), "Speed-up on the Tohoku Shinkansen and its impact on regional transport and economy”, World Conference Transport Research, Research for Tomorrow's Transport Requirements, Vancouver, pp. 1082-1849.

INSEE (2009a), Analyse fonctionnelle des emplois et cadres des fonctions métropolitaines, 6 p., http:// www.insee.fr/fr/ppp/bases-de-donnees/donnees-detaillees/analyse/ analyse_fonctionnelle_documentation_methodologique.pdf, retrieved 10/10/2015.

INSEE (2009b), « La créativité, clé de l'économie fondée sur la connaissance », Économie Lorraine, 199-200, December, http://www.insee.fr/fr/themes/document.asp?

reg_id=17\&ref_id=15751\&page=EL/EL199-200/EL199-200_2.htm, retrieved 10/10/2015.

JENSEN-BUTLER C., MADSEN B. (2005), “Transport and regional growth”, in BUTTON K.J. \& HENSHER D.A. (eds.), Handbook of Transport Strategy, Policy and Institutions, 6, Oxford, Elsevier, Handbooks in Transport, pp. 191-223.

JOLY I. (2003), « Les rapports espace-temps de la mobilité quotidienne et les systèmes productifs des transports urbains - Une analyse de la base UITP sur les systèmes de transport urbain de 100 villes du monde ", Atelier technique du Commissariat Général du Plan sur les transports urbains, présidé par Alain Bonnafous, pp. 99-189.

JOUVE B. \& LEFEVRE C. (eds.) (2004), Horizons métropolitains, Lausanne, Editions Presses Polytechniques et Universitaires romandes, $288 \mathrm{p}$. 
KANTOR S. (2008), The economic impact of the California high-speed rail in Sacramento/Central Valley Area, http://www.cahighspeedrail.ca.gov/images/ chsr/20081003135956_HSRCentralValleyReportFINAL-2.pdf, retrieved 10/10/2015.

LEE Y.S. (2007), A Study of the development and issues concerning High Speed Rail (HSR), Korea Railroad Research Institute and Transport Studies Unit, University of Oxford, Working paper $\mathrm{N}^{\circ} 1020$, Oxford University Centre for the Environment, http://www.tsu.ox.ac.uk/pubs/1020-lee.pdf.

MANNONE V. (1997), « Gares TGV et nouvelles dynamiques urbaines en centre-ville : le cas des villes desservies par le TGV Sud-Est », Les Cahiers Scientifiques du Transport, 31, pp. 71-97.

MAS S. (2011), Atlas des zones d'emploi 2010, INSEE, 84 p., http://www.insee.fr/fr/ppp/bases-dedonnees/donnees-detaillees/atlas-zone-emploi-2010/pdf/atlas-ze-2010.pdf, retrieved $10 / 10 / 2015$

MENERAULT P., BARRE A. (coll.) (2001), « Gares et quartiers de gares : signes et marges - Lille, Rennes et expériences internationales (Italie, Japon, Pays-Bas) », Actes du Séminaire international de Villeneuve d'Ascq du 22 mars 1999, 216 p.

MIGNEREY P. (2012), Les effets territoriaux de la grande vitesse ferroviaire en France, Paris, La Documentation française, DATAR, $94 \mathrm{p}$.

NICOLIN P. (ed.), (1995), « Il Tgv e l'effetto di surmodernità / The TGV and the hype of modernity ", Lotus International, Special issue, 86, pp. 30-91.

NVM Business (2015), Randstad office market 2015, Nieuwegein, 7 p.

OBSERVATOIRE DES TERRITOIRES (2015), « Part des cadres des fonctions métropolitaines en 2010 », DATAR, CGET, http://www.datar.gouv.fr/observatoire-des-territoires/sites/default/files/ images/231_R11_130731_PotentielDvlpt.png, retrieved 10/10/2015.

OCO GLOBAL (2007), Etude sur la perception de la Bretagne économique, 188 p.

OFFNER J.M. (1993), « Les “effets structurants” du transport : mythe politique, mystification scientifique ", L'Espace géographique, 22, 3, pp. 233-242.

OFFNER J.M. (2009), « En finir avec les effets structurants ! », Traits Urbains, December, 9.

OFFNER J.M. et al. (2014), Les effets structurants des infrastructures de transport, « Les controverses de l'Espace Géographique ", L'Espace Géographique, 1 (contributions by OFFNER J.M., BEAUCIRE F., DELAPLACE M., FRÉMONT A., NINOT O., BRETAGNOLLE A. \& PUMAIN D.).

OLLIVRO J. (1999), « Quand la vitesse recompose les territoires. Localisation des gares TGV et organisation urbaine », Annales des Ponts et Chaussées, 89, dossier « Gare et urbanisation », pp. 26-31.

PAULUS F. (2004), Coévolution dans les systèmes de villes : croissance et spécialisation des aires urbaines françaises de 1950 à 2000, PhD in Geography, University Paris 1-Sorbonne, 409 p., https:// tel.archives-ouvertes.fr/tel-00008053/document, retrieved 10/10/2015.

PLASSARD F. (2003), Transport et territoire, Paris, La Documentation française, 97 p.

RANDOLF S. (ed.) (2008), California high-speed rail economic benefits and impacts in the San Francisco Bay Area, San Francisco, Bay Area Council Economic Institute http:// www.cahighspeedrail.ca.gov/images/chsr/20081003150751_HSR\%20Bay\%20Area\%20Report\% 20Final.pdf.

RICHER C. (ed.) (2014), Évaluation des projets ferroviaires à grande vitesse. Aspects liés à l'accessibilité aux petites villes et territoires intermédiaires, réflexions issues d'études de cas en Europe, IFFSTAR-DEST, 
report to the Cerema, Paris, 74 p., http://www.infra-transports-materiaux.cerema.fr/IMG/ pdf/1431w-rapport_tgv_.pdf.

RICHER C., VUIDEL G. (2011), «L'intensité nodale, une évaluation de la performance de l'intermodalité dans les pôles d'échanges ", $10^{\text {èmes }}$ Rencontres de Théo Quant, Besançon, 23-25 février 2011, 16 p.

ROCHETTE C. (2012), «L'approche ressources et compétences comme clé de lecture du processus d'élaboration d'une ressource originale : la marque territoire ", Gestion et Management public, 1, pp. 4-20.

SAINT-JULIEN T. (2014), « Spatial Diffusion », Hypergeo, GDR Libergeo, http://www.hypergeo.eu/ spip.php?article187.

SETEC (2004), LGV PACA. Etude relative aux effets socio-économiques et en termes d'aménagement, Analyse bibliographique des effets des LGV. Synthèse du fonds documentaire, Paris, SETEC Organisation, 32 p., http://cpdp.debatpublic.fr/cpdp-lgvpaca/docs/pdf/etudes/etude_relative/LGV-PACAEffetTerritoire-Volet1-juin04.PDF.

TERRIN J.J. (dir.) (2011), Gares et dynamiques urbaines. Les enjeux de la grande vitesse, Marseille, Parenthèses, $223 \mathrm{p}$.

THIARD P. (2007), « La perspective urbaine est-elle soluble dans le marketing territorial? Réflexions sur l'évocation du futur dans l'évolution de la ville », Territoires 2030, 2, pp. 141-154.

TMO (1993), Ville de Rennes - La communication urbaine : images et attentes, report, 129 p.

TODOROVICH P., SCHNED D., LANE R. (2011), High speed rail international lessons for U.S. policy makers, Cambridge (Mass.), Lincoln Institute of Land Policy.

TRIP J.J. (2007), What makes a city? Planning for 'quality of place'. The case of high-speed train station area redevelopment, Amsterdam, IOS Press, OTB/Delft University of Technology PhD (proefschrift), $256 \mathrm{p}$.

TROIN J.F. (2010), « Désirs de gares TGV : du projet des édiles locaux au “désaménagement” du territoire », Belgeo, [en ligne] http://belgeo.revues.org/6647, retrieved 10/10/2015.

TSIOMIS Y. (ed.), ZIEGLER V. (2007), Anatomie de projets urbains : Bordeaux, Lyon, Rennes, Strasbourg, Paris, Editions de la Villette, $336 \mathrm{p}$.

UREÑA J.M., MENERAULT P. \& GARMENDIA M. (2009), “The high-speed rail challenge for big intermediate cities: A national, regional and local perspective", Cities, 26, 5, pp. 266-279.

URBANISME (2004), « Les valeurs de la ville, FNAU, interview de François Baroin, président de la CA de Troyes et député-maire de Troyes », hors-série, 24.

VAN PUYMBROECK C., REYNARD R. (2010), « Répartition géographique des emplois. Les grandes villes concentrent les fonctions intellectuelles, de gestion et de décision ", INSEE Première, 1278, February, 4 p., http://www.insee.fr/fr/ffc/ipweb/ip1278/ip1278.pdf, retrieved 10/10/2015.

WILLIGERS J. (2008), « The impact of high speed railways developments on offices locations : a scenario study approach", in BRUINSMA F., PELS E., PRIEMUS H., RIETVELD P. \& VAN WEE B. (eds.), Railway Development: Impacts on Urban Dynamics, Physica-Verlag.

\section{NOTES}

1. International Congress and Convention Association. 
2. If all scheduled housing units have been delivered in 1998, the surfaces allocated to new office have been dropped down from more than $13,000 \mathrm{~m}^{2}$ planned to less than 9,000 completed at the same date (Ménerault, Barré, 2001).

3. Société civile de placement immobilier ; i.e. Perial asset management.

4. Vente en l'état futur d'achèvement.

\section{ABSTRACTS}

Over the last decades, the metropolitan area of Rennes (Western France) has experienced a sharp demographic and economic dynamism compared with other similar French urban areas. The new high-speed line between Le Mans and Rennes (hereafter BPL HSL) to be opened in 2017 is carrying major expectations from local public actors. In this paper, we examine urban projects associated with the high-speed line in Rennes as tangible spatial expressions of a global prospective vision for Rennes post-BPL HSL. Analyzing the main factors explaining the vibrancy of the metropolitan area, we focus on the territorial positioning of Rennes and its attempts to capture the "HSL opportunity" and accelerate the current pace of socioeconomic dynamism. However, such an urban growth strategy introduces a sharp competition in the new office market between central projects and peripheral investments.

Depuis plusieurs décennies, l'aire métropolitaine de Rennes connait un dynamisme économique et démographique marqué. La nouvelle Ligne à Grande Vitesse ferroviaire entre Le Mans et Rennes (LGV BPL) attendue en 2017 suscite indiscutablement de fortes attentes de la part des acteurs locaux. Dans cet article, nous analysons les projets urbains rennais associés à l'arrivée de la très grande vitesse comme des manifestations spatiales de la vision métropolitaine postLGV BPL. Après avoir mis en exergue les principaux facteurs à l'origine du dynamisme de l'aire rennaise, nous tentons d'identifier à travers le positionnement territorial de la capitale bretonne le rôle de différents projets urbains concomitants à l'infrastructure dans l'appréhension et l'intégration de l'«opportunité LGV ». Pour autant, cette stratégie de croissance urbaine introduit une concurrence aiguë sur le marché des bureaux neufs entre les projets du centre-ville et les investissements en périphérie.

\section{INDEX}

Mots-clés: projet urbain, opportunité Ligne à Grande Vitesse, stratégies d'anticipation et d'accompagnement, concurrence intra-urbaine, Rennes

Keywords: urban project, high-speed line opportunity, anticipation and support strategies, intra-urban competition

\section{AUTHORS}

\section{ROMARIC NÈGRE}

ESO-Rennes (UMR CNRS 6590), University of Rennes 2, UFR Sciences Sociales, Place du Recteur Henri Le Moal, CS 24307, F-35043 Rennes CEDEX, France, romaric.negre@eiffage.com 
GUY BAUDELLE

ESO-Rennes (UMR CNRS 6590), University of Rennes 2, UFR Sciences Sociales, Place du Recteur Henri Le Moal, CS 24307, F-35043 Rennes CEDEX, France, guy.baudelle@univ-rennes2.fr 